\author{
PAWEŁ WOWRA \\ Uniwersytet Śląski w Katowicach \\ ORCID ID: https://orcid.org/0000-0001-5375-0719
}

\title{
Uwarunkowania mocarstwowości Chin
}

\section{Factors confirming China's power status}

\section{Abstract}

Nowadays it is no surprise to anyone that PRC is put on an equal footing with the USA. Current geopolitical situation is changing in inordinately dynamic way. The situation from a few years ago seems to be very different from what we have now. In a new, multipolar world China plays an increasing role. It has become the second world's economy after USA. There are many reasons that contributed to the current situation and it is not possible to address all of them in one thesis. Nonetheless, the important thing is to understand the reasons why China is becoming a geopolitical power.

The aim of this work is to analyze the strong and ceaselessly increasing China's position at the national level. Firstly, the changes that occurred in China over the past 70 years were analyzed. Analysis of the historical context helps to understand the dynamics of China's growth as well as immense potential of this country. The next part of the work addresses the events that took place in $21^{\text {st }}$ century with particular focus on 2008 crisis as well as its policy and economic implications that are noticeable in the present day. This part of the work also includes the assessment of China's dynamic development. In this work there is also a description of China's One Belt, One Road Initiative. Financial institutions associated with initiative as well as the opportunities for Europe connected with huge funds were described.

The work is based on the latest literature on the topic, online articles and statistics retrieved from People's Republic of China's official statistics website available in Chinese. 
The work shows that China plays an essential role in the new balance of power. Due to dynamic changes in the global balance of power China can become a leading superpower in the nearest future.

Keywords: Asia, China, superpower

\section{Факторы, обуславливающие положение Китая как сверхдержавы}

\section{Аннотация}

Ни для кого не новость, что в наше время Китайская Народная Республика находится на одной ступени развития с США. В нынешних условиях геополитическая ситуация меняется чрезвычайно динамично. Однако, буквально несколько лет назад ситуация кардинально отличалась от теперешней. В новом многополярном мире Китай играет все более важную роль - он становится второй крупнейшей мировой державой наряду с США. Причин нынешней ситуации много и все их невозможно учесть в одном исследовании. Важно, однако, понять причины и условия, благодаря которым Китай становится новой геополитической силой.

Цель этой работы - многогранный анализ сильной и постоянно укрепляющейся позиции Китая на международной арене. В самом начале исследования были проанализированы изменения, которые произошли в Китае за последние 70 лет. Анализ исторического контекста помогает понять динамику развития Китая, а также неисчерпаемый потенциал этой страны. В дальнейшей части работы предметом рассмотрения являются события, происходящие уже в XXI веке, с особым акцентом на кризис 2008 года, а также его политических и экономических последствий вплоть до сегодняшнего дня. На этом этапе также проводится оценка динамичного экономического развития Китайской Народной Республики. Исследование также включает описание китайской инициативы Нового Шелкового пути. Далее представлено описание финансовых институтов, связанных с этим предприятием, а также большие возможности для Европы в связи с открывающимся для освоения новым объёмом финансовых средств.

Исследование было создано на основе новейшей литературы по этой теме, онлайн статей и статистических данных, полученных с официального статистического веб-сайта Китайской Народной Республики, доступного на китайском языке. Исследование показывает, что Китай играет чрезвычайно важную роль в новой расстановке сил. Перед лицом динамичных изменений в мировом балансе сил, Китай может стать ведущей сверхдержавой уже в ближайшем будущем.

Ключевые слова: Азия, Китай, сверхдержава 


\section{Wprowadzenie}

Rozwój i zmiany w Chińskiej Republice Ludowej, jakie zaszły od lat 70. $\mathrm{XX}$ w., są ewenementem niespotykanym dotąd w historii. Chiny poprzez reformy zapoczątkowane podczas rządów Deng Xiaopinga przekształciły się stopniowo z państwa słabego gospodarczo i wycofanego na arenie międzynarodowej, w państwo o wiodącej roli w regionie i drugą gospodarkę świata. Jednocześnie z głównego antyglobalisty stały się państwem aktywnie działającym na rzecz globalnej integracji gospodarczej. Chiny są obecnie państwem bardzo aktywnym na arenie międzynarodowej i jednym z głównych aktorów kształtujących obecny światowy ład. Celem niniejszego opracowania jest w pierwszej kolejności syntetyczne przedstawienie rozwoju państwa od śmierci Mao Zedonga. Jest to kluczowe dla uzmysłowienia sobie jak szybko rozwija się to państwo i jak dynamicznie się zmienia. Następnie przedstawione zostaną czynniki, które zdeterminowały obecną pozycję Państwa Środka. Do takich elementów należy zaliczyć: wymiar gospodarczy kryzysu z 2008 r., przemiany polityczne w Europie i USA, przemiany gospodarcze i polityczne ChRL w XXI w. oraz realizowaną przez ChRL inicjatywę Nowego Jedwabnego Szlaku.

Każdy z tych czynników wymaga rozwinięcia. Zostaną one omówione w dalszej części opracowania.

\section{Rozwój Chin po śmierci Mao Zedonga}

\section{Mao i Deng}

Przed objęciem sterów państwa przez Deng Xiaopinga na czele Chin nieprzerwanie od 1949 r. stał Mao Zedong. Rządy Mao rozpoczęły się w kraju wyniszczonym półwieczem wojen domowych i wojen $\mathrm{z}$ wrogiem zewnętrznym. Komunistyczne hasła władzy ludu i władzy dla ludu padały na niezwykle podatny grunt. Postęp w pierwszych latach był widoczny, a Chiny powoli wydostawały się z głębokiej zapaści. Silna indoktrynacja i osławienie wspólnej pracy dla dobra wszystkich spowodowały wyzwolenie potencjału ogromnych mas ludzkich. Taki zabieg pozwolił Chinom na odnotowanie rzeczywistego postępu i rozwój państwa. Świat był w tym czasie 
ogarnięty zimną wojną, tak więc wobec przyjęcia komunizmu, a także bardzo negatywnego nastawienia Mao do państw kapitalistycznych, Chiny odcięły się od zachodniego handlu i finansów, a oparły się o Związek Sowiecki. Model sowiecki został przyjęty przy tym w ostatnich latach stalinizmu, gdy jego zgubna polityka była już oczywista (Gittings, 2010a). Brak relacji ze światem Zachodu i próba prowadzenia polityki za zamkniętymi drzwiami zatrzymała rozwój państwa, które z czasem zaczęło słabnąć. Późniejsze lata rządów Mao Zedonga to przede wszystkim zamknięcie się na jakiekolwiek wpływy zewnętrze i poszukiwanie samowystarczalności. Gradualizm pozostał jedynie w praktyce, a kolejne posunięcia Mao pokazały, że koniecznie chciał przyspieszyć drogę do komunizmu. Polityka wielkiego skoku (1951-1961) i rewolucja kulturalna (1966-1976) miały doprowadzić do prześcignięcia Zachodu "całkiem odmiennymi środkami” (Gittings, 2010b), a doprowadziły państwo do chaosu politycznego i niestabilnej sytuacji gospodarczej. Co prawda w latach 70. gospodarka chińska osiągnęła pewien stopień stabilności, jednak maoistowska polityka przynosiła coraz mniejsze zyski chińskiemu społeczeństwu, a idea „ciężkiego wysiłku i samowystarczalności” doprowadziła do izolacji. Konieczne okazało się otwarcie na świat, co jednak nie było możliwe za życia Mao Zedonga.

Śmierć Mao w 1976 r. spowodowała rozbicie politycznego betonu i dojście do władzy sił reformatorskich. Nowym przewodniczącym został Deng Xiaoping, który wraz ze skupionymi wokół siebie reformistami rozpoczął prowadzenie polityki czterech modernizacji. Był to plan zakładający gruntowne reformy i przekształcenia w czterech sektorach: obronności, przemysłu, rolnictwa oraz nauki i techniki. W praktyce hasło czterech modernizacji miało uzasadniać wolnorynkowe reformy gospodarcze. Polityka ta doprowadzała do odchodzenia od polityki samowystarczalności i stopniowego wprowadzania Chin do systemu światowego. Polityka otwartych drzwi, sukcesywne rozwijanie stosunków międzynarodowych, pakiet reform oraz liberalizacja życia gospodarczego wyzwoliły ogromny potencjał Państwa Środka. Przewodniczący Deng Xiaoping jasno dawał do zrozumienia, że polityka zamkniętych drzwi Mao doprowadziła kraj do słabości, a w obecnej sytuacji jeśli zmiany mają nastąpić, to tylko w kierunku większego otwarcia. Nowy przewodniczący w czasie swoich rządów, trwających faktycznie do 1989 r., wyznaczył kierunek rozwoju, który w efekcie pozwolił Chinom stopniowo stać się światowym mocarstwem. 
W praktyce, za czasów rządów Deng Xiaoping odsunięto się od idei socjalizmu. Do kolejnych praktycznych reform na szybko dorabiano uzasadnienie teoretyczne, by dalej reformować kraj w oparciu o przyjęty model. Chińscy dygnitarze słusznie zauważyli, że Chiny mogą być państwem otwartym i aktywnie grającym na arenie międzynarodowej, działającym w oparciu o autorytarny system władzy. Dostrzegli, że legitymizacja płynie od dołu, a otwarcie się i bogacenie chińskiego społeczeństwa umacnia legitymizację partii. Kolejne reformy w państwie wzmocniły jednak ruchy, które domagały się dużo dalej idących reform. W siłę urósł Ruch Demokratyczny, który stał się zagrożeniem dla jednowładztwa Komunistycznej Partii Chin. Napięcie między partią a reformatorami rosło, czego punktem kulminacyjnym była masakra na Placu Niebiańskiego Spokoju. Deng uważał, że autorytaryzm musi zostać utrzymany. W praktyce funkcjonuje do dziś.

\section{Zmiana układu sił}

Chiny z 1989 r. to wciąż podmiot słaby. Państwa Zachodu chciały szybko podporządkować sobie nowego gracza, który stopniowo się umacniał. Jeszcze pod koniec lat 90. ubiegłego wieku Chiny nie były państwem, z którym liczono się jako aspirującym do pozycji mocarstwa. Przełomem miał być 1991 r., gdy to upadek ZSRR ostatecznie przypieczętował erozję systemu jałtańsko-poczdamskiego, w którym dwa mocarstwa - USA i ZSRR - rywalizowały o pozycję hegemona w świecie. Państwa systemu euroatlantyckiego właśnie zwyciężyły w zimnej wojnie ze Związkiem Radzieckim, który nie był w stanie dalej sprostać rywalizacji gospodarczej. Żelazna kurtyna opadła. Od tamtego momentu to Ameryka zdawała się dominować wojskiem, gospodarką, zajmowała najważniejszą pozycję w świecie politycznym i kulturalnym. Potęga Stanów wyrażała się także hegemonią w Banku Światowym i Międzynarodowym Funduszu Walutowym. Powolny upadek ZSRR zbiegał się także w czasie z brutalną odpowiedzią Pekinu na protesty studenckie na placu Tian’anmen. Postulowano, że Chiny znów zmierzają w stronę maoizmu, co stanowiło punkt zapalny w relacjach ze światem zachodnim. Rozpad ZSRR - największego komunistycznego mocarstwa - miał być „końcem historii” i początkiem unipolarnego świata pod do- 
wództwem USA. Państwa Zachodu nałożyły dotkliwe sankcje, które miały zmusić Chiny do szybkiej liberalizacji i podporządkować je woli Zachodu. Ze słabymi Chinami miało pójść łatwo, jednak w krótkim czasie okazało się, że sankcje nie działają, a co gorsza - nie opłaca się ich utrzymywać. Reformy zapoczątkowane po śmierci Mao Zedonga przyniosły pierwsze efekty, a chłonny i ogromny rynek chiński okazał się potrzebny państwom Zachodu. Ponadto Chiny przyjęły od lat 90. politykę, która powoli przekształcała je w państwo o gospodarce rynkowej. Kolejne reformy wspomagane były przez napływający z Zachodu kapitał, a szybko rosnąca wymiana handlowa pozwalała bogacić państwo. Wydaje się, że wówczas nikt na Zachodzie nie zdawał sobie sprawy z potencjału jaki został uwolniony przez reformatorów na czele z Deng Xiaopingiem. Należy zaznaczyć, że bardzo istotny okazał się fakt, iż przemianom w sferze gospodarczej towarzyszyło utrzymanie monopartyjnego systemu, opartego na silnie scentralizowanej władzy. Jednowładztwo partii pozwoliło na prowadzenie reform w sposób stopniowy i uporządkowany. Niezmienność władzy pozwoliła na dążenie do ściśle określonego celu. Planując długofalowo plan przekształcenia państwa podjęty w 1976 r. był realizowany wciąż przez tych samych ludzi. Z kolei silna centralizacja pozwalała na szybkie reagowanie na przejściowe kłopoty. Zachód proponował rozwinięcie się w oparciu o liberalny model. Jednak chińscy dygnitarze zdecydowali, że transformacja nie będzie napędzana wolą odejścia od dotychczasowego ustroju, a wolą jak najszybszego przeprowadzenia modernizacji w oparciu o ten ustrój (Sapir, 2009a). Komunistyczna Partia Chin zaczęła stawać się dla chińskiego społeczeństwa gwarantem zaspokajania potrzeb materialnych i obrońcą interesu narodowego (Gittings, 2010c).

\section{Przemiany ostatnich lat i kryzys 2008}

\section{Przed kryzysem 2008}

Podczas gdy Chiny umacniały się gospodarczo, silne i rozwinięte państwa Zachodu napotykały kolejne przeszkody. Już na początku 1995 r., w kontekście wojny w byłej Jugosławii, okazało się że państwa europejskie nie są przychylne dominacji USA na scenie globalnej. Także rozpętane przez 
USA wojny w Afganistanie i Iraku przyczyniły się do erozji systemu euroatlantyckiego (Fiszer, 2014). Problemy USA i niezdolność do dzierżenia pozycji lidera światowego obnażył kryzys lat 1997-1999, który pokazał, że Stany Zjednoczone nie panują nad narzucaną światu międzynarodową liberalizacją finansów. Sam MFW przestał spełniać swoją rolę. Kolejne państwa odrzucały jego pomoc. Z drugiej strony polityka Chin zapewniała stabilność Dalekiego Wschodu (Sapir, 2009c), co jeszcze bardziej widoczne było w kryzysie z 2008 r. Problemy Stanów nie zmieniły jednak tego, że wciąż są najważniejszym, ale już nie jedynym, graczem na arenie międzynarodowej. Wciąż ważna jest także Unia Europejska, która także przeżywa kryzys i nie potrafi wypracować dla siebie jednolitej strategii. Obok nich pojawiły się Chiny, które przeżywają swój najlepszy okres.

\section{Wymiar gospodarczy kryzysu 2008}

XX w., począwszy od „wielkiej depresji” końca lat 20., naznaczony był wieloma kryzysami finansowymi, które regularnie implikowały recesję gospodarczą. Rynki finansowe rozwiniętych państw już od początku XX w. regularnie doświadczały kryzysów. Dotyczyło to nie tylko państw o stabilnym i rozwiniętym rynku, ale - co było nowością - także emerging markets: Tajlandii, Malezji, Indonezji, Meksyku, Brazylii czy Argentyny (Nawrot, 2009a). Kryzysy finansowe są na globalnym rynku zjawiskiem cyklicznym. Zauważyć należy jednak, że nie dotykały one w większym stopniu Chin, które w XX w. dopiero budowały swój potencjał. Co ważniejsze, Państwo Środka przez swoją politykę zamkniętych drzwi nie uczestniczyło w globalnym rynku, w efekcie nie będąc podatnym na jego wahania.

„Na początku 2007 roku na globalnym runku finansowym zaczął tlić się lont, jesienią 2008 roku eksplodował ładunek wybuchowy” (Nawrot, 2009b). Najbardziej interesujący nas kryzys to właśnie ten z jesieni 2008 r., który początkowo wydając się jedynie kryzysem na rynku nieruchomości USA szybko okazał się ogólnoświatowym problemem. Abstrahując od przyczyn kryzysu skupić należy się na jego skutkach. Pierwszym bezpośrednim skutkiem były ogromne straty instytucji finansowych, szczególnie tych, które agresywnie działały na rynku nieruchomości, zajmując się ryzykownymi kredytami. Były to głównie instytucje amerykańskie, jednak 
nie brakowało także podmiotów z innych państw. Bankructwo instytucji finansowych ciągnęło za sobą bankructwo przedsiębiorstw, co w efekcie powodowało kryzys gospodarczy i szybko rosnącą stopę bezrobocia, które to zjawisko przejawiło się szczególnie silnie w USA i UE. Kolejnym skutkiem była więc postępująca recesja gospodarcza. Przyjmuje się, że występujący dwa kwartały z rzędu ujemny wzrost PKB oznacza wkroczenie gospodarki w fazę recesji. Pod tym kątem, po wybuchu globalnego kryzysu w fazie recesji znalazły się m.in. Irlandia, Niemcy, Japonia, a w strefie zagrożenia pojawiły się m.in. Wielka Brytania czy Stany Zjednoczone. Również strefa euro wskutek kryzysu po raz pierwszy znalazła się w fazie recesji (Nawrot, 2009c).

Wielu ekonomistów przewidywało ten kryzys już od początku lat 90. XX w. W USA jego powodem były działania spekulacyjne na rynku nieruchomości, jednak wywarł on wpływ także na Unię Europejską i uwydatnił jej problemy. Wprowadzanie unii walutowej na obszarach charakteryzujących się różnymi stopniami rozwoju gospodarczego, bez wspólnej polityki fiskalnej i budżetu, skutkowało zadłużaniem się słabszych gospodarczo regionów, korzystających z nisko oprocentowanych kredytów. Ich wiarygodność była sztucznie podtrzymywana przez wiarygodność całej strefy dzięki gospodarce niemieckiej (Cianciara, 2013). W 2012 r. recesja objęła całą strefę euro. Kryzys odsłonił problemy nierównowagi rynków państw używających waluty euro. Okazało się, że odmiennie od oczekiwań, wprowadzanie wspólnej waluty wcale nie prowadzi do zatarcia różnic między gospodarkami państw. Przykład Grecji pociągnął za sobą lawinowo spadek zaufania do unii monetarnej i wydaje się, że w efekcie może to spowodować upadek całej idei. Noblista, a zarazem wybitny ekonomista Joseph E. Stiglitz, w rozmowie z „Polityką” przestrzegał Polskę przed wprowadzaniem waluty europejskiej. Wskazuje on, że późno zauważono, że kryzys nie jest winą Grecji, a całej strefy euro (Polityka, 2013). Wytyka on kolejne błędy w funkcjonowaniu strefy euro i zaleca jednocześnie pozostanie przy własnej walucie. 


\section{Przemiany polityczne w UE i USA}

Europa i USA są obecnie świadkiem dynamicznych przemian politycznych, a w szczególności rosnących w siłę prawicowych ugrupowań. W Europie ekonomicznym skutkom kryzysu towarzyszyło załamanie się wiary w niezawodność, a nawet słuszność dotychczasowego modelu. Zmiany wprowadzane kolejno w Nicei (2001) oraz Lizbonie (2007) doprowadziły do osłabienia Komisji oraz przyznania szczególnej roli Radzie Europejskiej i jej przewodniczącemu. Zredukowało to uczestnictwo małych państw w rządzeniu Unią i spowodowało zachwianie równowagi pomiędzy „silniejszymi” i „słabszymi” w Unii. Zjawisko wzmocnienia władzy Rady Europejskiej uwypukliło się szczególnie w dobie kryzysu. Martwiące dla wielu państw jest także powstanie Europejskiej Służby Działań Zewnętrznych osłabiające Komisję oraz wysunięta przez Antonio Tajaniego propozycja stworzenia stanowiska prezydenta Europy, który miałby być wybierany w wyborach bezpośrednich. Miałoby to nastąpić wskutek połączenia stanowisk przewodniczącego Komisji Europejskiej i Rady Europejskiej (Business Insider, 2017). Prowadziłoby to do zachwiania unijnego trójpodziału władzy i tworzyło wspólnotę opartą na silnym centralizmie. Nowe ramy instytucjonalne, niewyraźnie zakreślone w traktacie lizbońskim, wypełniane są kontrowersyjnymi decyzjami politycznymi. Decyzje podejmowane są w sposób coraz bardziej scentralizowany, a kolejnym państwom przestają odpowiadać szerokie kompetencje Unii. Kryzys wypunktował słabości Unii Europejskiej i wstrząsnął jej podwalinami. Okazało się, że podjęta w traktacie lizbońskim próba uczynienia z UE gracza globalnego zakończyła się fiaskiem i wymaga rewizji.

Spadek zaufania do Unii przejawia się coraz silniej w kolejnych państwach. Wystarczy wskazać tutaj na silną pozycję eurosceptycznego Viktora Orbana na Węgrzech, wynik powtórzonej drugiej tury wyborów prezydenckich w Austrii w 2017 r., w której to zwyciężył eurosceptyczny polityk Alexander Van der Bellen, a kanclerzem został sympatyzujący z europejskimi narodowcami Sebastian Kurz. Dalej są to wybory prezydenckie 2017 r. we Francji, w których do drugiej tury przeszła Marine Le Pen, stojąca na czele nacjonalistycznej i eurosceptycznej partii Front Narodowy. W siłę rośnie także eurosceptyczna i konserwatywna partia Alternatywa 
dla Niemiec (AfD), a we Włoszech w wyborach parlamentarnych z marca 2018 r. w głosowaniu proporcjonalnym najwięcej głosów zdobył Ruch Pięciu Gwiazd - kolejna eurosceptyczna partia. Lider ugrupowania, Luigi Di Maio, otwarcie wskazywał, że gdyby doszło do referendum to zagłosowałby za wyjściem ze strefy euro. Kryzys sięga jednak dużo dalej w przeszłość, gdyż już w 2005 r. we Francji i Niderlandach odrzucono „Konstytucję dla Europy”, w wyniku czego sztandarowy projekt ówczesnej Unii nie powiódł się.

W USA sytuacja jest o wiele bardziej przejrzysta. Wybory prezydenckie wygrał konserwatywny Donald Trump, szokując cały polityczny świat, który nie dawał mu szans. Wygrał on $\mathrm{z}$ o wiele bardziej liberalną Hillary Clinton. Jednak, jak się okazuje, na razie zmiana ta wychodzi Amerykanom na dobre. Ameryka przechodzi obecnie ponowny rozkwit gospodarczy, a polityka prezydenta Trumpa sprawdza się. W przypadku Chin istotna jest zapoczątkowana przez administrację Trumpa wojna gospodarcza z Państwem Środka, w której obie strony nakładają nowe taryfy celne na coraz większą ilość produktów. USA oskarża Chiny o niesprawiedliwe praktyki i dewaluację swojej waluty (Bussinessinsider, 2018). Chiny z kolei odpowiadają, że nie stosują niedozwolonych praktyk, w pełni przestrzegają wymogów Światowej Organizacji Handlu i wysuwają wzajemne oskarżenia o nieuczciwe praktyki i rozbijanie handlu międzynarodowego. Sytuacja jest napięta i jest w toku, jednak już teraz można zauważyć, że niechęć i agresywna polityka Stanów Zjednoczonych powoduje większe zainteresowanie Chin Europą.

\section{Przemiany gospodarcze i polityczne w ChRL}

Podczas gdy euroatlantycki świat pogrążony był w kryzysie, Chiny odczuły kryzys finansowy w dużo mniejszym stopniu. W jego dobie, zgodnie z danymi Międzynarodowego Funduszu Walutowego, tempo wzrostu PKB Chin w 2007 r. wyniosło 14,2\% i spadło do 9,2\% w 2009 r. Z kolei tempo wzrostu światowego PKB wyniosło w 2007 r. 5,3\% i spadło do -0,4\% w 2009 r. (Białowąs, 2014). Chińską gospodarkę napędzają przede wszystkim ogromne inwestycje oraz eksport netto. Konsumpcja wewnętrzna stanowi niewielki procent wzrostu gospodarczego państwa. Pomimo kryzy- 
su Chiny pozostały motorem napędowym wzrostu gospodarki światowej. Chiny zostały dotknięte kryzysem w dużo mniejszym stopniu niż reszta świata i kontynuowały wzrost, nastawiony teraz na rozbudowanie sektora usług oraz zbudowanie przewagi inwestycji wychodzących nad inwestycjami zagranicznymi. To drugie udało się po raz pierwszy w 2016 r. (Ambasada RP w Pekinie, 2017). Ponadto w 2015 r. bilans netto chińskich bezpośrednich inwestycji zagranicznych przewyższył wskaźniki amerykańskie.

Chiny są dalej największym eksporterem i drugim największym importerem na świecie. Wartość wymiany towarowej Chin w 2017 r. wyniosła 4 446,7 mld USD, w tym eksport 2 453,1 mld USD, a import 1993,6 mld USD. W 2017 r. (po spadku z 2016 r. względem 2015 r.) wartość wymiany wzrosła w zakresie eksportu o 12,1\%, a importu 26,8\%. Przewyższyła jednocześnie wyniki z 2014 r., który pod tym względem był rekordowy (wcześniej odnotowano spadki w latah 2015 i 2016). Chiny osiągnęły nadwyżkę obrotów towarowych z zagranicą, wynoszącą 459,5 mld USD (www. stats.gov.cn, 2018c). Jak zaznaczono wyżej, Chiny nastawiają się na rozwój sektora usług i wyjście owego sektora za granicę. Widać to także w statystykach eksportu i importu. W stosunku do zeszłego roku eksport usług wzrósł o 10,6\% i wyniósł 246,5 mld USD, podczas gdy import usług wzrósł o 5,1\% i wyniósł 505,3 mld USD. Rozbieżność wciąż jest znacząca, jednak poprawia się z roku na rok.

Chiny umacniają także swoją pozycję na rynkach w regionie Afryki, Azji, Bliskiego Wschodu czy Ameryki Łacińskiej. Wymiana między Chinami a Afryką od 1999 do 2010 r. wzrosła dwudziestokrotnie, w tym samym czasie z państwami Bliskiego Wschodu wzrosła o 87\%. Obecnie wzrasta jeszcze szybciej, w związku z realizacją inicjatywy Nowego Jedwabnego Szlaku.

Zmiany objęły także społeczeństwo chińskie. W momencie przejęcia władzy przez Deng Xiaopinga w miastach chińskich mieszkało $162 \mathrm{mln}$ ludzi, co stanowiło zaledwie $17 \%$ ogółu ludności. Obecnie jest to zawrotna liczba 813 mln ludzi. Wciąż jest to jednak 58,5\% społeczeństwa, co stawia Chiny w jednym rzędzie z emerging markets. Fakt ten jest o tyle interesujący, że państwo to posiada drugą co do wielkości gospodarkę świata. Obserwujemy przy tym stałą tendencję wzrostową, która oscyluje cały czas w okolicach 3\% rocznie (www.stats.gov.cn, 2018a). Ważną statystyką jest także poziom życia ludzi. Od 1990 r. ze skrajnej biedy wyprowadzono re- 
kordową liczbę osób. Jeszcze w 1990 r. 66,6\% Chińczyków musiało przeżyć za mniej niż 2 dolary amerykańskie dziennie. Do 2000 r. odsetek ten zmniejszył się do 40\%, a niewiele mniejszy odsetek społeczeństwa żył poniżej krajowego poziomu ubóstwa. Z początkiem XXI w. Komunistyczna Partia Chin stawiła sobie za cel walkę z biedą i procent ten zaczął spadać w niezwykle szybkim tempie. Zgodnie z danymi Banku Światowego, dostępnymi jedynie do 2014 r., odsetek ten spadł do 1,4\%. Z kolei z oficjalnych danych wynika, że obecnie już nie $40 \%$ obywateli żyje poniżej krajowego poziomu ubóstwa, a jedynie $10 \mathrm{mln}$, co stanowi 0,7\% ludności (w Chinach poziom ubóstwa to przychód mniejszy niż 400 dolarów rocznie). Gorzej sytuacja wygląda, gdy weźmiemy za wyznacznik 5,5 dolara amerykańskiego na dzień. W tym wypadku w 1990 r. 98,3\% (!) Chińczyków żyło za mniej niż wyżej podana kwota. Dziś ten procent wciąż jest względnie wysoki i wynosi $21 \%$ ludności, co daje około 300 mln ludzi. Należy jednak mieć na uwadze, że jeszcze w 2000 r. był to ponad $1 \mathrm{mld}$ ludzi. Oczywiście wciąż znaczna liczba obywateli żyje w slumsach, zwiększa się także rozwarstwienie społeczne, a współczynnik Giniego wyniósł w 2016 r. 41,5. Szacuje się jednak, że pomimo postępującego rozwarstwienia społecznego (co jest normalne dla tak rozwiniętych gospodarek) poziom życia będzie rosnąć, urbanizacja postępować, a liczba ludzi żyjących za mniej niż 5,5 dolara amerykańskiego dziennie spadnie do 100 milionów w 2025 r. Zmniejsza się też liczba ludzi żyjących poniżej granicy skrajnego ubóstwa, która w Chinach wynosi ok. 340 dolarów rocznie. Na koniec 2017 r. było to 3,1\% wobec $4,5 \%$ w 2016 r. W samym 2017 r. ze skrajnej biedy wyciągnięto 13 mln ludzi (www.stats.gov.cn, 2018b).

Państwo doświadcza także przekształceń politycznych. W tym przypadku z niestabilną politycznie Unią kontrastują zjednoczone pod silnym przywództwem Xi Jinping'a Chiny. Podczas gdy nie wiadomo w jakim kierunku powinna pójść integracja europejska oraz czy w ogóle jest ona zasadna, świat obiegła informacja o zmianie przepisu Konstytucji Chin, który stanowił, że każdorazowy Przewodniczący ChRL może pełnić 5-letnią kadencję maksymalnie dwukrotnie (China Daily, 2018). Dokonano zmiany $\mathrm{w}$ treści przepisu $\mathrm{z}$ „The term of office of the President and Vice-President of the People's Republic of China is the same as that of the National People's Congress, and they shall serve no more than two consecutive terms" na "The term of office of the President and Vice-President of the People's Republic of 
China is the same as that of the National People's Congress". Tym samym $\mathrm{Xi}$ Jinping będzie pozostawał u władzy tak długo, jak długo pozwoli na to jego autorytet w kręgach partii. Możliwe, że do końca życia. Jego pozycję wzmaga propozycja inkorporacji do Konstytucji ChRL „Myśli Xi Jinping'a o socjalizmie $z$ charakterystyka w Nowej Erze" wysunięta przez Komitet Centralny Komunistycznej Partii Chin (Xinhua, 2018). Pozycja Xi zbliża się do pozycji Mao. Tradycją od czasów Mao jest wpisywanie ideologii przywódców Państwa Środka do konstytucji, natomiast Xi Jinping jest drugim od czasów Mao Zedonga, który został wymieniony w niej z nazwiska. Pierwszy był Deng Xiaoping, jednak Xi Jinping dokonał tego za życia.

\section{Nowy Jedwabny Szlak, obietnica chińskich miliardów}

\section{Czym jest Nowy Jedwabny Szlak?}

By uzmysłowić sobie potencjał i rolę Chin w kształtowaniu ładu międzynarodowego nie sposób pominąć kwestii Nowego Jedwabnego Szlaku. Czym jest Nowy Jedwabny Szlak? Jest to najogólniej mówiąc koncepcja polityki zewnętrznej i wewnętrznej Chin, narzędzie do realizacji chińskich interesów w zmieniającym się świecie, umacniania pozycji supermocarstwa i budowania pozycji hegemona. Odmiennie jednak od wielu porozumień i inicjatyw, jak chociażby TPP - Trans-Pacific Partnership (Partnerstwo Transpacyficzne), które to było umową planowaną przez dwanaście krajów w całym regionie Azji i Pacyfiku, Chiny nie tworzą jednej umowy, z góry zakreślając które państwa mogą, a które nie mogą przystąpić. Nie stosują dla żadnego państwa z góry określonych warunków. Jest to otwarty projekt, do którego może dołączyć każde państwo globu (Schiller Institute, 2014). Jedwabny Szlak porównywany jest czasem do planu Marshalla, jednak Chińczycy dość stanowczo odrzucają takie porównania. W połowie 2013 r. Xi Jinping ogłosił realizację dwóch koncepcji - Ekonomicznego Pasa Jedwabnego Szlaku, a więc lądowego szlaku, biegnącego przez całą Azję Środkową, łączącego Chiny z Europą oraz Morskiego Jedwabnego Szlaku XXI w., który połączy się z lądowym. Cała inicjatywa występuje jako ,jeden pas jedna droga” (chin. 一带一路, eng. One Belt One Road) (Tsui, 2017a). Nowy Jedwabny Szlak to planowana sieć autostrad, superszybkich kolei oraz szlaku morskiego. 
Od czasu ogłoszenia inicjatywy Chiny stopniowo uzbrajają ową koncepcję w zaplecze instytucjonalne i finansowe oraz realizują kolejne składowe projekty, które mają na sam koniec utworzyć Nowy Jedwabny Szlak. Swoim zasięgiem obejmuje on państwa o ogromnym potencjale demograficznym i gospodarczym. Państwa te obejmują $65 \%$ światowej populacji oraz są odpowiedzialne za wytworzenie 50\% światowego PKB.

\section{Nowe instytucje finansowe}

Tak wielkie przedsięwzięcie to także ogromne wymogi finansowe. W tym celu utworzono wiele instytucji finansowych, z których na szczególne uwzględnienie zasługują trzy: Silk Road Fund (Fundusz Jedwabnego Szlaku, SRF), New Development Bank (Bank Nowego Rozwoju, NDP) oraz wydaje się, że najważniejszy: Asian Infrastructure Investment Bank (Azjatycki Bank Inwestycji Infrastrukturalnych, AIIB). Silk Road Fund to instytucja zarejestrowana 29 grudnia 2014 r. w Pekinie. Zarządza ona kapitałem w wysokości 40 mld USD, które ChRL planuje przeznaczyć na „budowę dróg, kolei i lotnisk wzdłuż Jedwabnego Szlaku w Azji Centralnej i Południowej w celu promocji ekonomicznej współpracy i politycznych związków”. Xi Jinping wskazuje jednak, że poza inwestycją środków własnych, fundusz ma przyciągać inwestorów z Azji, a także innych regionów świata (Nobis, 2017a). New Development Bank to międzynarodowy bank powołany 15 lipca 2014 r. przez państwa grupy BRICS: Brazylię, Rosję, Indie, Chiny oraz Republikę Południowej Afryki. Wiceprezes banku wskazał, że państwa założycielskie obejmują 43\% ludności świata oraz 22\% światowego PKB (Nobis, 2017b). Państwa te powołały instytucję dla finansowania długoterminowych inwestycji oraz dla bardziej stabilnego rozwoju. Bank jest odpowiedzią na wymogi emerging markets w regionie, których potrzeby w zakresie inwestycji infrastrukturalnych, według wyliczeń ekonomistki Stephany Griffith-Jones, sięgają biliona dolarów amerykańskich (Griffith-Jones, 2014a). Sam bank początkowo dysponował kapitałem w wysokości 50 mld dolarów amerykańskich, który ma zwiększyć się do 100 mld dolarów (Griffith-Jones, 2014b).

Z punktu widzenia Europy najważniejszą spośród powołanych instytucji finansowych jest Azjatycki Bank Inwestycji Infrastrukturalnych (AIIB). 
Jest to międzynarodowa instytucja finansowa $\mathrm{z}$ siedzibą $\mathrm{w}$ Pekinie, tworzona formalnie od października 2014 r. (Kalwasiński, 2017a). Co ważne, deklaracje o udziale w funduszu zgłosiły największe gospodarki Europy - Wielka Brytania, Niemcy i Francja. Z państw współpracujących z Chinami w formacie 16+1 (państwa Europy Środkowo-Wschodniej) Polska jest jedynym potencjalnym członkiem założycielem (Prospective Founding Member) funduszu. Wkład Polski do funduszu to $831,8 \mathrm{mln}$ USD, co zapewnia jej $0,98 \%$ siły głosów. Inicjatywa początkowo była silnie krytykowana przez USA, które poddawało wątpliwości zgodność działania funduszu z wymogami kreowanymi przez Bank Światowy, jednak pod naciskiem opinii międzynarodowej, ostatecznie zaakceptowało stworzenie funduszu (Kalwasiński, 2017b). Same Stany Zjednoczone, podobnie jak Japonia czy Kanada, nie są uczestnikami funduszu. AIIB działa formalnie od 25 grudnia 2015 r., gdy 17 państw, których udział wynosi 50,1\% ratyfikowało status. 31 grudnia 2015 r. ostatnie z 57 państw założycielskich złożyło podpis pod statutem. Bank dysponuje kapitałem w wysokości 100 mld USD, z czego $20 \%$ to kapitał włożony, w pozostałym zakresie jest to kapitał wpłacany na żądanie. Zgodnie ze statutem celem banku jest wspieranie zrównoważonego rozwoju ekonomicznego, tworzenie dobrobytu i poprawa łączności w Azji przez inwestycje w infrastrukturę oraz inne sektory produkcyjne oraz promowanie współpracy regionalnej i partnerstwa w rozwiązywaniu wyzwań rozwojowych przez bliską współpracę z innymi multilateralnymi oraz bilateralnymi instytucjami rozwojowymi (Statut AIIBa). Jest to fundusz regionalny, w pierwszej kolejności na inwestycje w Azji, jednak w tym miejscu należy wskazać na art. 11 ust. a Statutu: „Bank może zapewnić lub ułatwić finansowanie projektu: każdemu członkowi, każdej agencji, innemu podmiotowi prawa publicznego lub jego jednostce terytorialnej niższego szczebla, lub każdemu podmiotowi i przedsiębiorstwu działającemu na terytorium jednego z państw członków (...)” (Statut AIIBb). Artykuł ten należy powiązać z wypowiedziami Radosława Pyffela, który w 2017 r. został mianowany zastępcą dyrektora i członkiem Rady Dyrektorów. W rozmowie z Pulsem Biznesu wskazał on, że Bank będzie inwestował w Europę, a szczególnie ważnym miejscem dla Chin jest Polska, jako że to do Polski wiodą najszybsze bezpośrednie połączenia kolejowe z Chin. AIIB jest rozpatrywany jako potencjalny inwestor w budowę Centralnego Portu Lotniczego, hubów i centrów logistycznych. Bank jest zainteresowany inwe- 
stycjami w regionie Europy Środkowo-Wschodniej, szczególnie w Polsce, która ze względu na istniejące połączenia oraz położenie geograficzne stanowi bramę do Europy. Polska mogłaby się stać spichlerzem Chin bądź europejskim centrum rozładunkowym i logistycznym w handlu Chin z Europą. Należy przy tym wskazać na zmiany, jakie mają nastąpić w unijnych finansach po 2020 r. Po 2020 r. Polska może już nie otrzymywać od Unii dużego wsparcia, a powodów jest kilka. Po pierwsze jest to wyjście z UE drugiego największego płatnika - Wielkiej Brytanii. Kolejnym powodem jest kryzys migracyjny i chęć zmiany polityki finansowej w kierunku obronności i migracji, co ma pochłaniać znaczną część środków unijnych. Rozważane jest także, aby państwom, którym Komisja Europejska zarzuca nieprzestrzeganie zasad UE nie wypłacać unijnych pieniędzy (Obserwator Finansowy, 2017). Po 2020 r., gdy fundusze europejskie będą się kończyć, efektywna współpraca z Państwem Środka, a co za tym idzie z AIIB, będzie procentować (Puls Biznesu, 2017). AIIB stanowi jednocześnie platformę internacjonalizacji dla polskich i europejskich firm. Fundusz pozwoli w sposób bezpieczniejszy pod względem finansowym na realizowanie przedsięwzięć w Azji.

\section{AIIB a instytucje Bretton Woods}

Azjatycki Bank Inwestycji Infrastrukturalnych jest często rozpatrywany jako konkurencyjna instytucja dla Banku Światowego oraz Międzynarodowego Funduszu Walutowego (MFW). Rzeczywiście należy wskazać, że jest to inicjatywa państw emerging markets na czele z Chinami wynikająca $\mathrm{z}$ braku zgody na zdominowanie przez bogate państwa Zachodu międzynarodowych instytucji finansowych oraz próba budowania swojej pozycji na scenie globalnej (Kalwasiński, 2017c). Niezadowolenie Chin nie powinno dziwić. Udział Chin w Azjatyckim Banku Rozwoju wynosi 5,5\% i jest ponaddwukrotnie niższy od udziału USA i Japonii (12,8\%). Należy przy tym pamiętać, że gospodarka Japonii jest trzykrotnie mniejsza niż chińska. Podobnie sytuacja ma się w Międzynarodowym Funduszu Walutowym, gdzie udział państw BRICS (23\% światowego PKB) wynosi 14\%, podczas gdy udział czterech największych państw UE (15\% światowego 
PKB) to $16 \%$. Same Chiny w MFW mają dwukrotnie mniejszy udział niż USA i minimalnie mniejszy od Japonii (Kalwasiński, 2017d).

Celem Chin nie jest przy tym niszczenie i wystąpienie z istniejących międzynarodowych instytucji finansowych, ale tworzenie funduszy uzupełniających i w szerszy sposób uwzględniających interesy emerging markets. Chiny zdają sobie sprawę z niemożności wyparcia dolara oraz zepchnięcia USA z pozycji lidera, ze względu na to, że budowa pozycji USA trwa nieprzerwanie od zeszłego stulecia, a po II wojnie światowej to właśnie Stany Zjednoczone wygenerowały około $50 \%$ światowego PKB. Nowe instytucje finansowe mają być przeciwwagą dla tych istniejących i pomóc Chinom budować własną pozycję w nowym, multipolarnym ładzie międzynarodowym (Tsui, 2017b). Instytucje Bretton Woods są krytykowane także za brak elastyczności, który przejawia się w narzucaniu pożyczkobiorcom neoliberalnej polityki gospodarczej, bez względu na to czy dane państwo jest na to gotowe. Wiarygodność instytucji Bretton Woods podważył jeszcze mocniej kryzys z 2008 r. Malezja, która nie skorzystała z pomocy MFW podczas kryzysu notowała później lepsze wyniki gospodarcze. Z kolei Indonezja czy Tajlandia, które implementowały strategie odczuwały realne problemy (Wróblewski, 2009). Korzystanie z pomocy okazało się niekorzystne także dla Grecji, Hiszpanii czy Portugalii, których zadłużenie zwielokrotniło się wskutek spadku PKB i napływu środków funduszu. Inicjatywa Chin, które stawiają przede wszystkim na współpracę w wymiarze horyzontalnym jest ciekawą alternatywą.

\section{Wnioski}

Dynamicznie zmieniająca się sytuacja na arenie międzynarodowej, gospodarcze i polityczne przemiany zachodzące w USA, Europie i Chinach przekształcają dotychczas znany porządek światowy. Z powyższych rozważań można wysunąć pewne wnioski, które w części pojawiały się już w treści opracowania:

- Chiny już w tym momencie dzierżą miano światowego mocarstwa. Przy obecnym tempie rozwoju państwa to właśnie one w niedalekiej przyszłości mogą stać się najsilniejszym państwem świata. Obecnie Chiny dysponują już nie tylko ogromnym potencjałem gospodar- 
czym, demograficznym i bardzo chłonnym rynkiem, ale wskutek wzbogacenia się chińskiego społeczeństwa i położenia przez partię nacisku na edukację, Chiny posiadają wielką liczbę wysoce wykwalifikowanych pracowników;

- utrata przez USA statusu mocarstwa i lidera w unipolarnej rzeczywistości zrodziła multipolarny świat, w którym świetnie odnajdują się Chiny. Optowanie za wspólnym rozwojem i współpracą na zasadzie partnerstwa wpisuje się w retorykę Chin w budowaniu relacji na arenie międzynarodowej. Taka sytuacja jest szczególnie sprzyjająca dla dalszego rozwoju sztandarowej inicjatywy Nowego Jedwabnego Szlaku jako propozycji realizacji interesów na zasadzie win-win;

- retoryka Chin w stosunkach międzynarodowych, akcentująca poszanowanie dla odrębności i nienarzucająca własnych rozwiązań, kontrastuje $\mathrm{z}$ dotychczasowym zachowaniem państw euroatlantyckich w budowaniu własnych relacji. Rodzi to sytuację, w której Państwo Środka staje się interesującym partnerem do rozmów. Problemem w tym wypadku jest jednak brak wiarygodności tego nowego partnera, brak wypracowanych modelów i form współpracy oraz różnice kulturowe utrudniające kooperację;

- owym problemom naprzeciw wychodzi inicjatywa Nowego Jedwabnego Szlaku, która poza wielkimi finansami i inwestycjami jest także bardzo bogata w wymianę ludzką i kulturową. Coraz większe rzesze studentów i ludzi biznesu rozumieją język, a przede wszystkim kulturę i ludzi Państwa Środka;

- przemiany polityczne w Europie, zawiedzionej rozwiązaniami proponowanymi przez Unię Europejską, pchają państwa Unii w stronę dbania o własne partykularne interesy. Z jednej strony sytuacja ta nie jest korzystna dla Chin, gdyż te w rywalizacji z USA potrzebują zjednoczonej Europy, która tylko w taki sposób może być silnym partnerem. Z drugiej strony jest to możliwość do zbudowania silnych relacji z poszczególnymi państwami i w efekcie umocnienie swojej pozycji w regionie;

- Chiny w stronę Europy pcha także wojna handlowa z USA. Dowodzi tego ostatnia wizyta premiera Chin w Niemczech i jego kolejne 
wypowiedzi. Chiny tworząc w świecie przeciwwagę dla USA, będąc wciąż słabszym państwem, polegają na Unii jako jednym ze swoich głównych partnerów handlowych o wielkim potencjale gospodarczym i ludzkim. Rosnące w Europie zainteresowanie Państwem Środka i kolejne proponowane programy w ramach Nowego Jedwabnego Szlaku zarówno dla przedsiębiorców, jak i studentów mogą w niedalekiej przyszłości zadecydować o ścisłej współpracy;

- planowane cięcia w funduszach europejskich, wymogi infrastrukturalne regionu oraz nowe instytucje finansowe powinny prowadzić do wniosku, że rozwijanie współpracy z Chinami może być niezwykle istotne w dalszej perspektywie. Chiny już teraz są jednym z najsilniejszych państw świata. Współpraca bazująca na partnerstwie i wzajemnym zrozumieniu pozwoli na szersze otwarcie rynku chińskiego na Europę i rynków europejskich na Chiny.

\section{PAWEL WOWRA}

Wydział Prawa i Administracji

Uniwersytet Śląski

Międzywydziałowe Koło Kultury i Prawa Chińskiego

ul. Bankowa 11b, 40-007 Katowice

wowra.pawel1@gmail.com

\section{Bibliografia}

Białowąs, T. (2014). Inwestycje a wzrost gospodarczy Chin w latach 1980-2012. Annales Universitatis Mariae Curie-Skłodowska. Sectio H. Oeconomia, 48(2), 19-29.

Cianciara, A. K. (2013). Wewnętrzne uwarunkowania polityki zewnętrznej Unii Europejskiej w kontekście kryzysu gospodarczego. W: J. Fiszer (red.). System euroatlantycki i bezpieczeństwo międzynarodowe w multipolarnym świecie. Miejsce i rola Polski $w$ euroatlantyckim systemie bezpieczeństwa. Warszawa: Instytut Studiów Politycznych Polskiej Akademii Nauk.

Fiszer, J. M. (2013). System euroatlantycki przed i po zakończeniu zimnej wojny. Istota, cele i zadania oraz rola $w$ budowie nowego ładu globalnego. Warszawa: Instytut Studiów Politycznych Polskiej Akademii Nauk.

Fiszer, J. M. (red.). (2014). System euroatlantycki w wielobiegunowym świecie. Próba prognozy. Warszawa: Instytut Studiów Politycznych Polskiej Akademii Nauk. 
Gittings, J. (2010). Historia współczesnych Chin. Od Mao do gospodarki rynkowej. Kraków: Wydawnictwo Uniwersytetu Jagiellońskiego.

Griffith-Jones, S. (2014). A Brics Development Bank: A Dream Coming True? UNCTAD Discussion Papers 215, United Nations Conference on Trade and Development.

Kajdański, E. (2011). Chiny. Leksykon. Warszawa: Książka i Wiedza.

Kalwasiński, M. (2017). Ekonomia XXI wieku. Wrocław.

Nawrot, W. (2009). Globalny kryzys finansowy XXI wieku. Warszawa: CeDeWu.

Nobis, A. (2017). Krótki przewodnik po Nowym Jedwabnym Szlaku. Wrocław: Stara Szuflada.

Sapir, J. (2009). Nowy XXI wiek. Od „Wieku Ameryki” do powrotu narodów. Warszawa: Wydawnictwo Akademickie „Dialog”.

Sit Tsui, Erebus Wong, Lau Kin Chi, Wen Tiejun. (2017). One Belt, One Road. China's Strategy for a New Global Financial Order.

Statut AIIB.

Wróblewski, M. (2009). Międzynarodowy Fundusz Walutowy i Bank Światowy wobec kryzysów finansowych. Toruń: Wydawnictwo Adam Marszałek.

\section{Netografia}

Strona internetowa Ambasady RP w Pekinie. Pobrane z: www.pekin.msz.gov.pl/pl/ wspolpraca_dwustronna/wspolpracagospodarcza/sytuacja_gospodarcza_chin/.

Businessinsider. Pobrane z: businessinsider.com.pl/finanse/makroekonomia/wojnahandlowa-to-koniec-dla-gospodarki-societe-generale/k0nnv4h.

Business Insider Polska. Pobrane z: www.businessinsider.com.pl/polityka/polaczeniestanowisk-szefa-komisji-europejskiej-i-rady-europejskiej/xjhgr7t.

China Daily. Pobrane z: http://www.chinadaily.com.cn/a/201802/25/WS5a927386a31 06e7dcc13dece.html.

National Bureau of Statistic of China. Pobrane z: www.stats.gov.cn.

Obserwator Finansowy. Pobrane z: www.obserwatorfinansowy.pl/forma/rotator/ rozpoczyna-sie-gra-o-finanse-ue-po-2020-r/.

Polityka. Pobrane z: www.polityka.pl/tygodnikpolityka/swiat/1550521,1,noblistaradzi-polsce-nie-porzucajcie-zlotowki.read.

Puls Biznesu. Pobrane z: www.pb.pl/pyffel-aiib-bedzie-finansowac-takze-inwestycjew-polsce-858796.

The International Schiller Institute. Pobrane z: www.newparadigm.schillerinstitute. $\mathrm{com} / \mathrm{media} /$ the-new-silk-road-is-transforming-the-planet-a-new-era-of-mankind/.

Xinhuanet. Pobrane z: http://www.xinhuanet.com/english/2018-02/25/c_136999028. htm. 